Fagopyrum 38 (1): 15-23 (2021)

Research paper

\title{
Response of common buckwheat and Tartary buckwheat from different elevations to selenium treatment
}

\author{
Aleksandra GOLOB ${ }^{1}$, Neja LUZAR ${ }^{1}$, Mateja GERM ${ }^{1 *}$ \\ 1 Biotechnical Faculty, University of Ljubljana, Jamnikarjeva 101, 1000 Ljubljana, Slovenia \\ * Corresponding author: Biotechnical Faculty, University of Ljubljana, Jamnikarjeva 101, 1000 Ljubljana, Slovenia \\ Tel: +38613203334; mateja.germ@bf.uni-lj.si;
}

E-mail addresses: aleksandra.golob@bf.uni-lj.si; neja.luzar2@gmail.com

DOI https://doi.org/10.3986/fag0019

Received: April 26, 2021; accepted May 8, 2021.

Keywords: common buckwheat, Tartary buckwheat, elevation, selenium, morphological characteristics, biochemical characteristics

\begin{abstract}
Common buckwheat and Tartary buckwheat were grown in Slovenia outdoors at different elevations - $300 \mathrm{~m}, 600$ $\mathrm{m}$ and $1180 \mathrm{~m}$ a.s.l. Both species were foliarly treated with selenium twice (in the vegetative phase and in the flowering phase). The effects of Se treatment and different growing locations on selected biochemical, physiological and anatomical traits were monitored. In Se treated common buckwheat, amount of chlorophylls was higher in plants from Ljubljana (the lowest elevation - $300 \mathrm{~m}$ a.s.l.) than in plants grown in Podbeže (600 m a.s.l.), whereas in control group, plants grown in Ljubljana contained more chlorophylls than plants from Javorje (the highest elevation - $1180 \mathrm{~m}$ a.s.l.). In both buckwheat species, Se alone did not affect amount of chlorophylls in any of location. In Se treated common buckwheat plants, the amount of UV absorbing compounds was the highest in plants, grown at the highest elevation. In common buckwheat, Se lowered the number of $\mathrm{CaOx}$ in plants, grown in Javorje. Conditions at different elevations, as well as treatments with Se, did not affect potential and effective photochemical efficiency of Photosystem II.
\end{abstract}

Ključne besede: navadna ajda, tatarska ajda, nadmorska višina, selen, morfološke značilnosti, biokemijske značilnosti

\section{IZVLEČEK}

Navadno ajdo in tatarsko ajdo smo na prostem gojili na različnih nadmorskih višinah - na $300 \mathrm{~m}, 600 \mathrm{~m}$ in 1180 $\mathrm{m} \mathrm{n}$. m. Rastline obeh vrst smo dvakrat foliarno tretirali s selenom (v vegetativni fazi in v fazi cvetenja). Spremljali smo učinke tretiranja s Se in lokacije na izbrane biokemijske, fiziološke in anatomske lastnosti rastlin. Pri navadni ajdi, 
tretirani s Se, iz Ljubljane (najnižja nadmorska višina - $300 \mathrm{~m} \mathrm{n.} \mathrm{m.)} \mathrm{je} \mathrm{bila} \mathrm{vsebnost} \mathrm{klorofila} \mathrm{večja} \mathrm{kot} \mathrm{v} \mathrm{rastlinah} \mathrm{iz}$ Podbež (600 m n. m.), rastline iste vrste iz kontrolne skupine iz Ljubljane pa so vsebovale več klorofila kot tiste iz Javorja (najvišja nadmorska višina $-1180 \mathrm{~m} \mathrm{n}$. m.). Dodatek Se ni na nobeni lokaciji povzročil razlik v vsebnosti klorofilov v primerjavi s kontrolno skupino. Vsebnost UV absorbirajočih snovi v s Se tretirani navadni ajdi je bila največja v rastlinah, gojenih na najvišji nadmorski višini. Na omenjeni nadmorski višini je Se znižal število kristalov Ca-oksalata v navadni ajdi. Niti razmere na različnih nadmorskih višinah niti dodatek Se niso vplivali na potencialno in dejansko fotokemično učinkovitost fotosistema II. 


\section{INTRODUCTION}

Buckwheat (Fagopyrum), a genus of dicotyledons from the family Polygonaceae, has spread to Europe and elsewhere in the world from southwest China. The area of origin of wild ancestors of the most nutritionally important species of buckwheat today - common buckwheat (F. esculentum Moench) and Tartary buckwheat (F. tataricum (L.) Gaertn.) - are supposedly the Chinese provinces of Yunnan and Sichuan (Ohnishi, 1998). It was recently reported that Tartary buckwheat originated in western China (Zhang et al., 2021). F. esculentum and F. tataricum are used in human nutrition, while the wild species Fagopyrum cymosum is used in traditional Chinese human and veterinary medicines (Luthar et al., 2021). Buckwheat is considered as pseudocereal (Huda et al., 2021) and belongs to the family Polygonaceae (Martinčič et al., 2007). Buckwheat has many health benefits for humans due to its contents of resistant starch, mineral elements, proteins, and especially phenolic substances, which prevent the effects of several chronic human diseases, including hypertension, obesity, cardiovascular diseases, and gallstone formation (Luthar et al., 2021). Flavonoids have a beneficial effect on human health (Panche et al., 2016). They play an important antioxidant role (Treml and Šmejkal, 2016). A nutritionally important flavonoid with strong antioxidant activity is rutin. It is present in many plants, with buckwheat standing out among plants in terms of its content (Kreft et al., 2002). Different parts of the buckwheat plant vary in rutin content: it is present in leaves and flowers in higher concentrations than in seeds, but the latter can nevertheless contribute significantly to the daily intake of flavonoids in the human diet (Kreft et al., 2002). Differences in rutin content are also present between different types of buckwheat.

Plants from Polygonaceae family contain numerous calcium oxalate ( $\mathrm{CaOx}$ ) druses (Nakata, 2012). The biological functions of $\mathrm{CaOx}$ druses in plants are not completely understood (Franceschi et al., 2015). They take part in the regulation of the bulk free Ca levels in plant tissues and organs, protection against herbivory and detoxification (e.g. heavy metals) (Franceschi and Nakata, 2005). Other possible functions of $\mathrm{CaOx}$ druses include role in regulation of ion balance, providing mechanical support in plant tissues and gathering and reflection of light (Nakata, 2012).

The climate of the Alpine region is very complex. The altitudinal gradient is related to decreased air tempera- ture and pressure, increased precipitation, and changes in wind exposure, soil fertility and duration of snow cover (Caldwell et al., 1980). The increase in UV-B radiation (290-320 nm) ranges from between 6 and 8\% (Caldwell et al., 1980) to $20 \%$ (Blumthaler et al., 1993) per 1,000 m of elevation.

Radiation with different wavelengths has different effects on plant growth and development. They can stimulate photosynthesis, activate specific photoreceptors and/or cause in most cases harmful photomodifications of macromolecules (Verdaguer et al., 2017). Both photosynthetic active radiation as well as UV-A and UV-B radiation affect Photosystem II (PSII). Their excessive intensities can lead to excessive excitation of PSII reaction centers and photooxidation damage to thylakoid membranes (Štroch et al., 2008). UV radiation triggers defense mechanisms in most plants that involve the synthesis of UV-absorbing substances, such as flavonoids (Štroch et al., 2008; Lim et al., 2021). Flavonoids are polyphenolic substances that perform various functions in plants: they protect plants against UV-B radiation, they are important for attracting plant pollinators, and play a role in allelopathy (Rozema et al., 1997). They also act as antioxidants and increase plant resistance to disease; some, for example, have antifungal effects (Harborne and Williams, 2000).

While selenium (Se) is known to be essential for animals, there is currently no evidence of its essentiality for plants (Hasanuzzaman et al., 2020; Trippe III and Pilon-Smits, 2021). However, it can be classified among beneficial elements. These are elements that can have a stimulating effect on plant growth in certain (low) concentrations, but are not necessarily necessary for plants (Pilon-Smits et al., 2009). Selenium plays important roles in human and animal organisms (Smoleń et al., 2014). Treating plants with Se can have a stimulating effect on their growth and development (Hasanuzzaman et al., 2020; Rady et al., 2020). It can increase their antioxidant capacity and resistance to biotic (Trippe III and Pilon-Smits, 2021) and abiotic stress such as drought (Rady et al., 2020). Selenium could be also added for the preparation, or supplemented to the diet (Germ et al., 2009).

Aim of the present paper was to find out the response of two species of buckwheat to conditions at different elevations and possible effect of adding selenium to their biochemical, physiological and anatomical characteristics. 


\section{MATERIALS AND METHODS}

\section{Experimental set up}

Plants of common buckwheat (Fagopyrum esculentum Moench) and Tartary buckwheat (F. tataricum (L.)

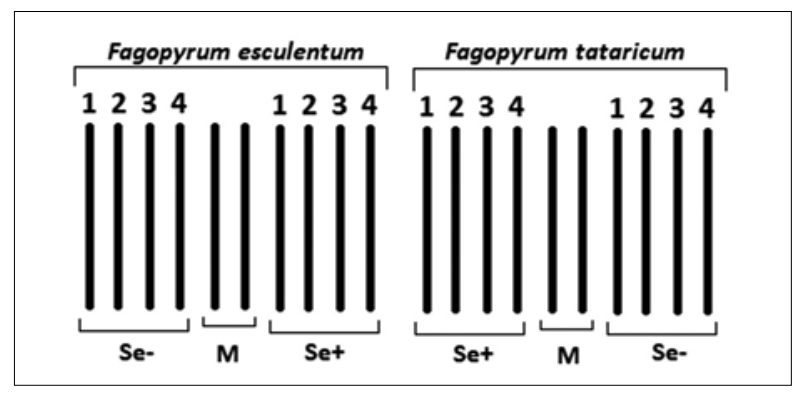

Fig. 1: Schematic representation of the experimental field. An individual vertical represents a row of plants. The designation Se+ means treatment with selenium, Se- means the control group (without treatment with selenium), M means group of each species, where plants were not treated with Se, and samples were not taken.
Gaertn.) were grown from seeds in different locations with different elevations: in Ljubljana (300 $\mathrm{m}$ above sea level), in Podbeže, the municipality of Ilirska Bistrica (600 $\mathrm{m}$ above sea level) and in Javorje, the municipality of Črna na Koroškem (1180 m above sea level). Half of the experimental plants were foliarly treated twice with solution of potassium selenate (K2SeO4) with Se concentration of $10 \mathrm{mg} \mathrm{L}^{-1}$. First treatment was at the vegetative phase (seedling age 40 days) and the second treatment was at the beginning of the flowering phase. Scheme of the experiments in Ljubljana, Podbeže and Javorje, is illustrated below (Fig. 1).

\section{Biochemical and physiological analyses}

The content of chlorophyll a, b and carotenoids was determined following the method by Lichtenthaler and Buschmann (2001a and 2001b). Weighed piece of fresh leaf was homogenized in a mortar and extracted in $6 \mathrm{~mL}$ acetone (90\%). Homogenate of samples, extracted in 90\% acetone was centrifuged for 4 minutes at $4000 \mathrm{rpm}$

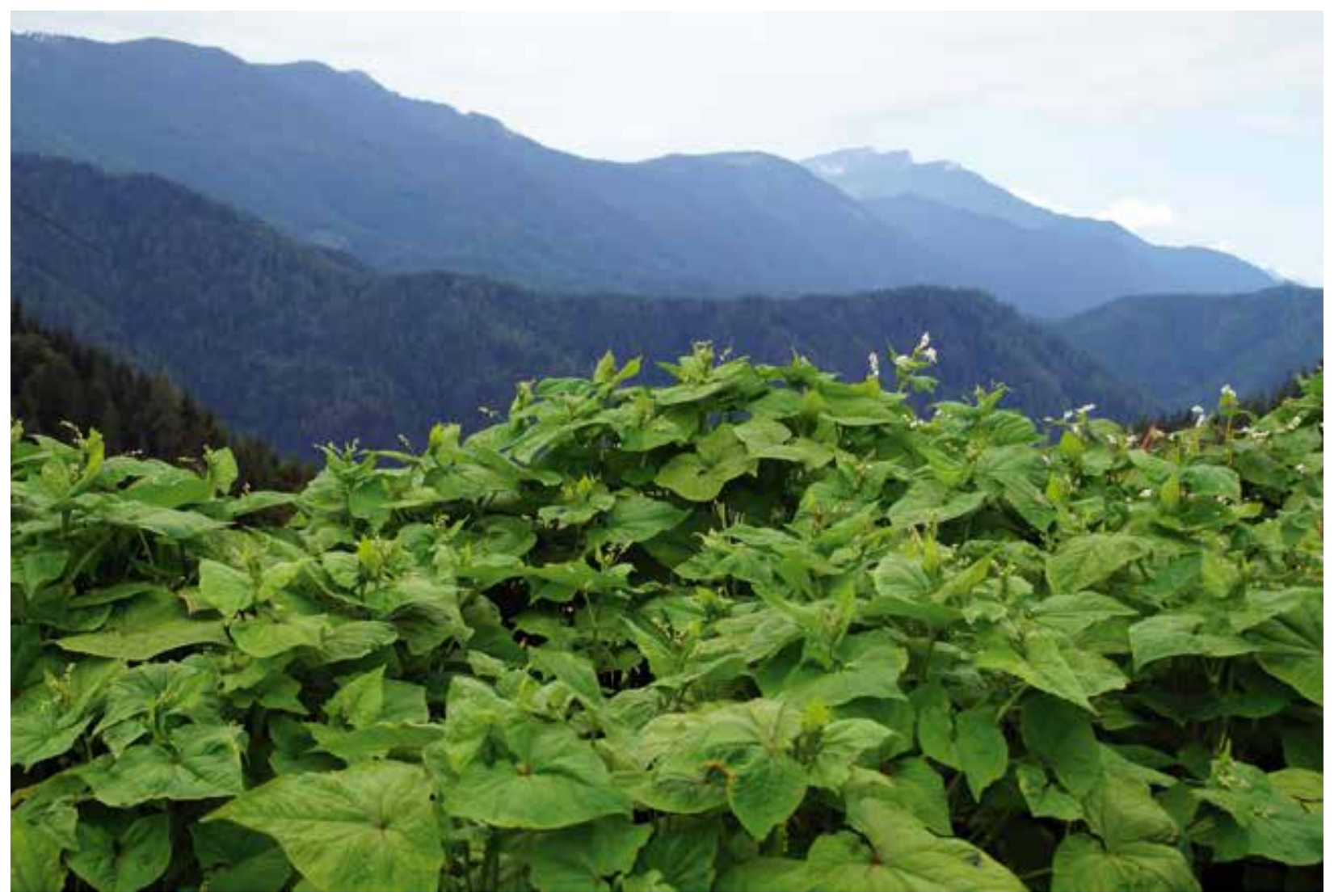

Fig. 2: Experimental site at Stopar family ecological farm "Mežner" in Javorje (1180 m above sea level), near Črna na Koroškem. At the left Tartary buckwheat plants, right common buckwheat plants. 
and $4{ }^{\circ} \mathrm{C}$. After centrifugation, the volume of the extract was measured. Then extinction measurements using a VIS spectrophotometer (Lambda 12; PerkinElmer, Inc., Waltham, MA, USA;) at different wavelengths $(470 \mathrm{~nm}$, $645 \mathrm{~nm}$ and $662 \mathrm{~nm}$ ) were done. Using the measured extinction values, the content of chlorophyll $\mathrm{a}$ and $\mathrm{b}$ and carotenoids per unit dry weight of the sample was calculated.

The anthocyanin levels were determined according to Lindoo and Caldwell (1978). The lyophilized plant tissue was first grounded. The samples were covered and incubated for 48 hours in a dark at a temperature of $3-5^{\circ} \mathrm{C}$. The absorbances of the extracts were measured at 530 nm using a UV/VIS spectrometer (Lambda 25; PerkinElmer, Inc., Waltham, MA, USA). The anthocyanins were extracted from the weighed dry plant material with $\mathrm{HCl}$ :methanol:water $=1: 79: 20(\mathrm{v} / \mathrm{v} / \mathrm{v})$. The homogenate was centrifuged for 4 minutes at $4000 \mathrm{rpm}$ and $4^{\circ} \mathrm{C}$. The absorbance of the extracts was measured at $530 \mathrm{~nm}$ using a UV/VIS spectrometer (Lambda 25; PerkinElmer, Inc., Waltham, MA, USA). The anthocyanin levels are expressed in relative units. After centrifugation, the volume of the extract was measured.

For UV-absorbing substances, measurements were made at wavelengths from 280 to $400 \mathrm{~nm}$. The sum of absorption values in the range $280-315 \mathrm{~nm}$ was used to calculate UV-B absorbing compounds, and the sum of absorption values in the range $316-400 \mathrm{~nm}$ was used to calculate UV-A absorbing compounds.

The photochemical efficiency of PSII, measured by Fv/Fm ratio $(\mathrm{Fv} / \mathrm{Fm}=(\mathrm{Fm}-\mathrm{Fo}) / \mathrm{Fm})$ was measured using a portable chlorophyll fluorometer (PAM 2500; Walz, Effeltrich, Germany). Fv is a variable fluorescence, Fo and Fm are minimal and maximal chlorophyll a fluorescence yield in dark adapted sample. For dark adaptation, the samples were kept in cuvettes for 20 min before measurement. Fluorescence was excited with a saturating beam of "white light" (photosynthetic photon flux density, $8000 \mu \mathrm{mol} \mathrm{m}^{-2} \mathrm{~s} ; 0.8 \mathrm{~s}$ ). The effective quantum yield was determined by a saturating pulse of "white light" using a standard 60o angle clip, under saturating irradiance. Measurements were done at the prevailing ambient temperature. The yield coefficient was defined as follows: $\mathrm{Y}=$ (Fm' - FO')/Fm'; Fm' is the maximum and FO' the minimum fluorescence of an irradiated sample (Schreiber et al., 1998).

\section{Analyses of $\mathrm{CaOx}$ druses}

The numbers of the $\mathrm{CaOx}$ druses were determined on transverse sections using light microscopy (CX41; Olympus, Japan) with a digital camera (XC30; Olympus, Japan) and the CellSens software (Olympus, Japan).

\section{RESULTS AND DISCUSSION}

Conditions at different elevations have minor effects on the amount of chlorophylls, and UV absorbing compounds (Table 1).

Selenium was reported to enhance, lower or to not have any effect on the amount of chlorophylls. Photosynthetic pigments of cowpea leaves were significantly enhanced by the foliar application of $\mathrm{Na}$ selenate up to $25 \mu \mathrm{M}$, but inhibited at high concentrations $(50 \mu \mathrm{M})(\mathrm{El}$ Lateef Gharib et al., 2019). In another study (Golob et al., 2018b), Se in the same concentration as in the present study increased the chlorophyll $\mathrm{a}$ and $\mathrm{b}$ and carotenoid contents per $\mathrm{mm}^{2}$ of leaf area in Tartary buckwheat. On the other hand, it was recently reported that foliar spray-

Table 1: Biochemical, physiological and anatomical characteristics in Se-treated and control common buckwheat leaves.

\begin{tabular}{c|c|c|c|c|c|c|c}
\hline \multirow{2}{*}{\multicolumn{2}{c|}{}} & \multicolumn{5}{c}{ Se+ } & \multicolumn{3}{c}{ Se- } \\
\cline { 3 - 8 } & \multicolumn{4}{c}{ Common buckwheat - treatment: } \\
\hline Parameter & Unit & Ljubljana & Podbeže & Javorje & Ljubljana & Podbeže & Javorje \\
\hline Total chlorophylls & $\mathrm{mg} / \mathrm{g} \mathrm{dm}$ & $18,8 \pm 1 \mathrm{a}$ & $12,7 \pm 0,9 \mathrm{c}$ & $16,2 \pm 1,9 \mathrm{a}, \mathrm{b}, \mathrm{c}$ & $18,1 \pm 1,7 \mathrm{a}, \mathrm{b}$ & $14,3 \pm 1,1 \mathrm{~b}, \mathrm{c}$ & $13,6 \pm 0,3 \mathrm{c}$ \\
\hline $\begin{array}{c}\text { UV-absorbing } \\
\text { compounds }\end{array}$ & $\begin{array}{c}\text { relative } \\
\text { units }\end{array}$ & $255 \pm 21 \mathrm{~b}$ & $218 \pm 19 \mathrm{~b}$ & $360 \pm 48 \mathrm{a}$ & $242 \pm 33 \mathrm{~b}$ & $226 \pm 18, \mathrm{~b}$ & $275 \pm 15 \mathrm{~b}$ \\
\hline No. of CaOx druses & $/$ & $23,6 \pm 0,7 \mathrm{a}$ & $18,4 \pm 1,6 \mathrm{~b}, \mathrm{c}$ & $18 \pm 1,5 \mathrm{c}$ & $22,6 \pm 0,3 \mathrm{a}$ & $20,6 \pm 0,7 \mathrm{a}, \mathrm{b}, \mathrm{c}$ & $21,5 \pm 0,7 \mathrm{ab}$ \\
\hline
\end{tabular}

Data are means \pm standard error $(n=4$ for each treatment). Different letters indicate significant differences between different treatments, ( $p<0,05$; Duncan Post Hoc Test).

Legend: Se+, added selenium; Se-, no added selenium; dm, dry matter 
ing with $10 \mathrm{mg} \mathrm{L}^{-1}$ Se in the form of selenite and selenate, did not have any effects on the amount of chlorophyll a and chlorophyll b in chicory (Germ et al., 2020). The latter was evidenced also from the present study, where plants were foliarly sprayed with the same concentration of Se (Table 1, Table 2). However, there were some differences in amount of chlorophylls between plants of the same species and treatment from different elevations (Table 1, Table 2). In Tartary buckwheat, the only difference regarding the amount of chlorophylls was present between untreated plants from Javorje and Podbeže, with latter having lower amount of chlorophylls (Table 2). However, this was not the case in common buckwheat. In untreated common buckwheat plants from Javorje, amount of chlorophylls was lower than in untreated plants grown in Ljubljana. In Se treated plants of the same species from Ljubljana, amount of chlorophylls was higher than in plants of the same treatment from Podbeže (Table 1). It seems that in certain cases plants from higher elevations contained lower amount of chlorophylls. Similar results were given by Roblek et al. (2008), who studied biochemical reponse of Hypericum perforatum to the conditions at different elevations. In Se treated common buckwheat plants, the amount of UV-absorbing compounds was the highest in plants, grown at the highest elevation. UV-absorbing compounds protect plants from potential damage (Van de Staaij et al., 1995). The highest amounts of UV absorbing compounds were measured also in in Hypericum perforatum from higher elevations (Roblek et al., 2008). In Tartary and common buckwheat plants from Javorje, Se treatment induced the accumulation of UV-absorbing compounds (Table 1, Table 2). It was already known that Se increases contents of UV-absorbing compounds and anthocynins in hybrid buckwheat (Golob et al., 2018a).
In common buckwheat, Se lowers the number of $\mathrm{CaOx}$ in plants, grown in Javorje (Table 1). Similar results were given by Golob et al. (2018b) for Tartary buckwheat, where Se decreased the density of $\mathrm{CaOx}$ druses in plant leaves. Toxic metals (cadmium, lead, copper and zinc) had an effect on mechanisms that mediate crystal formation in Corchorus olitorius (jute) and Malva parviflora (cheeseweed) (Faheed et al., 2013). Maybe similar case for the negative effects of $\mathrm{Se}$ on $\mathrm{CaOx}$ druses synthesise was present also in common buckwheat in the present study. In Se treated common buckwheat plants, the number of $\mathrm{CaOx}$ druses was highest at the lowest elevation (Table 1), whereas in Tartary buckwheat plants, the number of $\mathrm{CaOx}$ druses was higher in plants from Ljubljana than in plants from Podbeže (in Se treated plants), and in plants from Ljubljana than in plants from Javorje (in untreated plants) (Table 2).

Values of potential photochemical efficiency of PSII ranged between 0,572 and 0,807 (average value 0,752 ) in common buckwheat, and between 0,647 and 0,820 (average value 0,765 ) in Tartary buckwheat (data not shown). This is indicator that all experimental plants had good fitness, and also that neither conditions at different elevations nor the addition of Se posed stress to the common and Tartary buckwheat. It has already been shown in many studies that Se does not influence the potential photochemical efficiency of PSII, such as in cihory, treated with $10 \mathrm{mg} \mathrm{Se} \mathrm{L}^{-1}$ (Golob et al., 2020), and red cabbage plants treated with $2 \mu \mathrm{g} \mathrm{L}^{-1} \mathrm{Se}$ (Mechora et al., 2011).

To conclude, we presume that both species are adapted to the conditions present at higher elevation. In addition, neither Se in concentrations used in this study nor different elevation posed stress to the plants. Se treatment increased the amount of UV-absorbing compounds

Table 2: Biochemical, physiological and anatomical characteristics in Se-treated and control Tartary buckwheat leaves.

\begin{tabular}{c|c|c|c|c|c|c|c}
\hline \multirow{2}{*}{\multicolumn{2}{c|}{}} & \multicolumn{5}{c}{ Se+ } & \multicolumn{3}{c}{ Se- } \\
\cline { 3 - 8 } & \multicolumn{4}{c}{ Jartary buckwheat - treatment: } \\
\hline Parameter & Unit & Ljubljana & Podbeže & Javorje & Ljubljana & Podbeže & Javorje \\
\hline Total chlorophylls & $\mathrm{mg} / \mathrm{g} \mathrm{dm}$ & $17,6 \pm 3 \mathrm{a}$ & $16 \pm 1,2 \mathrm{a}, \mathrm{b}$ & $17,7 \pm 1,6 \mathrm{a}$ & $13,3 \pm 2 \mathrm{a}, \mathrm{b}$ & $10,6 \pm 1 \mathrm{~b}$ & $17,3 \pm 1,7 \mathrm{a}$ \\
\hline $\begin{array}{c}\text { UV-absorbing } \\
\text { compounds }\end{array}$ & $\begin{array}{c}\text { relative } \\
\text { units }\end{array}$ & $258 \pm 17 \mathrm{a}, \mathrm{b}$ & $225 \pm 55 \mathrm{a}, \mathrm{b}$ & $293 \pm 19 \mathrm{a}$ & $206 \pm 29 \mathrm{a}, \mathrm{b}$ & $216 \pm 36 \mathrm{a}, \mathrm{b}$ & $166 \pm 27 \mathrm{~b}$ \\
\hline No. of CaOx druses & $/$ & $20 \pm 2,2 \mathrm{a}$ & $13,4 \pm 0,6 \mathrm{~b}$ & $16,3 \pm 2,3 \mathrm{a}, \mathrm{b}$ & $20,7 \pm 1,4 \mathrm{a}$ & $16,9 \pm 1,8 \mathrm{a}, \mathrm{b}$ & $13,8 \pm 1,6 \mathrm{~b}$ \\
\hline
\end{tabular}

Data are means \pm standard error $(n=4$ for each treatment). Different letters indicate significant differences between different treatments, $(p$ $<$ 0,05; Duncan Post Hoc Test).

Legend: Se+, added selenium; Se-, no added selenium; dm, dry matter 
in plants of both species grown at the highest elevation, and decreased the number of $\mathrm{CaOx}$ druses in common buckwheat from the highest elevation. However, Se did not affect the amount of chlorophylls in plants of neither species. There were some differences in the amount of chlorophylls between common buckwheat plants as well as between Tartary buckwheat plants from different elevations. The number of $\mathrm{CaOx}$ druses was highest in Se treated common buckwheat plants from the lowest elevation. In untreated Tartary buckwheat plants from the lowest elevation, it was higher than in plants from the highest elevation. In Se treated Tartary buckwheat grown at the lowest elevation, the number of $\mathrm{CaOx}$ druses was higher than in plants of the same species and treatment from Podbeže. Based on the results of photochemical efficiency of PSII measurements, experimental plants of both buckwheat species from Se treated and control group from all locations were in good physiological condition.

\section{ACKNOWLEDGEMENT}

This study was funded by the Slovenian Research Agency, grant numbers P1-0212, J7-9398, J7-9418 and L4-9305, the latter was cofinanced by the Ministry of Agriculture, Forestry and Food, Republic of Slovenia.

\section{REFERENCES}

Blumthaler M., Ambach W., Huber M. 1993. Altitude effect of solar UV radiation dependent on albedo, turbidity and solar elevation. Meteorol. Zeitschrift 2, 3, 116-120.

https://doi.org/10.1127/metz/2/1993/116

Caldwell M. M., Robberecht R., Billings W. D. 1980. A steep latitudinal gradient of solar ultraviolet-B radiation in the artic-alpine life zone. Ecology 61, 3, 600-611. https://doi.org/10.2307/1937426

El Lateef Gharib F. A., Zeid I. M., Ghazi S. M., Ahmed E. Z. 2019. The Response of Cowpea (Vigna unguiculata L.) Plants to Foliar Application of Sodium Selenate and Selenium Nanoparticles (SeNPs). J. Nanomater. Mol. Nanoechnol. 8, 4. https://doi.org/10.4172/2324-8777.1000272

Faheed F. A., Mazen A., Abd Elmohsen S. 2013. Physiological and ultrastructural studies on calcium oxalate crystal formation in some plants, Turk. J. of Bot. 37, 139-152. https://doi.org/10.3906/bot-1112-19

Franceschi V. R., Nakata P. A. 2005. Calcium oxalate in plants: formation and function. Annu. Rev. of Plant Biol. 56, 41-71. https://doi.org/10.1146/annurev.arplant.56.032604.144106

Germ M., Kacjan-Maršić N., Kroflič A., Jerše A., Stibilj V., Golob A. 2020. Significant accumulation of iodine and selenium in chicory (Cichorium intybus L. var. foliosum Hegi) leaves after foliar spraying. Plants 1766, 12, 1-10. https://doi.org/10.3390/plants9121766

Germ M., Stibilj V., Kreft S., Gaberščik A., Pajk F., Kreft I. 2009. Selenium concentration in St. John`s wort (Hypericum perforatum L.) herb after foliar spraying of young plants under different UV-B radiation levels. Food Chem. 117, 2, 204-206. https://doi.org/10.1016/j.foodchem.2009.03.099

Golob A., Novak T., Kacjan-Maršić N., Šircelj H., Stibilj V., Jerše A., Kroflič A., Germ M. 2020. Biofortification with selenium and iodine changes morphological properties of Brassica oleracea L. var. gongylodes) and increases their contents in tubers. Plant Physiol. Biochem. 150, 234-243. https://doi.org/10.1016/j.plaphy.2020.02.044

Golob A., Stibilj V., Kreft I., Vogel-Mikuš K., Gaberščik A., Germ M. 2018a. Selenium treatment alters the effects of UV radiation on chemical and production parameters in hybrid buckwheat. Acta Agric. Scan. B Soil Plant Sci. 68, 1, 5-15. https://doi.org/10.1080/09064710.2017.1349172

Golob A., Stibilj V. Nečemer M. Kump P., Kreft I., Hočevar A., Gaberščik A., Germ M. 2018b. Calcium oxalate druses affect leaf optical properties in selenium-treated Fagopyrum tataricum. J. Photochem. Photobiol. B, Biol. 180: 51-55.

https://doi.org/10.1016/j.jphotobiol.2018.01.018

Harborne J. B., Williams C. A. 2000. Advances in flavonoid research since 1992. Phytochemistry 55, 481-504. https://doi.org/10.1016/s0031-9422(00)00235-1

Hasanuzzaman M., Bhuyan M. H. M. B., Raza A., Hawrylak-Nowak B., Matraszek-Gawron R., Al Mahmud J., Nahar K., Fujita M. 2020. Selenium in plants: Boon or bane? Environ. Exp. Bot. 178, 104170.

https://doi.org/10.1016/j.envexpbot.2020.104170 
Huda Md. N., Lu Shuai, Jahan T. Ding M., Jha R., Zhang K., Zhang W., Georgiev M. I., Park S. U., Zhou M. 2021. Treasure from garden: Bioactive compounds of buckwheat. Food Chem. 335, 127653. https://doi.org/10.1016/j.foodchem.2020.127653

Kreft S., Štrukelj B., Gaberščik A., Kreft I. 2002. Rutin in buckwheat herbs grown at different UV-B radiation levels: comparison of two UV spectrophotometric and an HPLC method. J. Exp. Bot. 53, 375, 1801-1804. https://doi.org/10.1093/jxb/erf032

Lichtenthaler H. K., Buschmann C. 2001a. Extraction of Photosynthetic Tissues: Chlorophylls and Carotenoids. In: Current Protocols in Food Analytical Chemistry, John Wiley \& Sons, Inc., New York, pp. F4.2.1-F4.2.6. https://doi.org/10.1002/0471142913.faf0402s01

Lichtenthaler H. K., Buschmann C. 2001b. Chlorophylls and Carotenoids: Measurement and Characterisation by UV-VIS Spectroscopy. Current Protocols in Food Analytical Chemistry, John Wiley \& Sons, Inc., New York, pp. F4.3.1-F4.3.8. https://doi.org/10.1002/0471142913.faf0403s01

Lim Y. J., Lyu J. I., Kwon S.-J., Eom S. H. 2021. Effects of UV-A radiation on organ specific accumulation and gene expression of isoflavones and flavonols in soybean sprout. Food Chem. 339, 128080. https://doi.org/10.1016/j.foodchem.2020.128080

Lindoo S. J., Caldwell M. M. 1978. Ultraviolet-B Radiation-induced Inhibition of Leaf Expansion and Promotion of Anthocyanin Production: Lack of Involvment of the Low Irradiance Phytochrome System. Plant Physiol. 61, 278-282. https://doi.org/10.1104/pp.61.2.278

Luthar Z., Golob A., Germ M., Vombergar B., Kreft I. 2021. Tartary buckwheat in human nutrition. Plants 10, 4, 1-14. https://doi.org/10.3390/plants10040700

Madronich S., McKenzie R. L., Björn L. O., Caldwell M. M. 1998. Changes in biologically active ultravioet radiation reaching the Earth's surface. J. Photochem. Photobiol. B, Biol. 46, 5-19. https://doi.org/10.1016/S1011-1344(98)00182-1

Martinčič, A., Wraber T., Jogan, N., Podobnik A., Turk B., Vreš B., Ravnik V., Frajman B., Strgulc Krajšek S., Trčak B., Bačič T., Fischer M. A., Eler K., Surina B. 2007. Mala flora Slovenije - Ključ za določanje praprotnic in semenk.; 4. Izd. Ljubljana: Tehniška založba Slovenije: 967 str.

Mechora Š., Stibilj V., Radešček T., Gaberščik A., Germ M. 2011. Impact of Se(VI) fertilization on Se concentration in different parts of red cabbage plants. J. Food. Agric. Environ. 9, 2, 357-361. https://www.researchgate.net/publication/264701215

Nakata, P. A. 2012. Plant calcium oxalate crystal formation, function, and its impact on human health. Font. Biol. 7, 3 , 254-266. https://doi.org/10.1007/s11515-012-1224-0

Ohnishi O. 1998. Search for the Wild Ancestor of Buckwheat III. The Wild Ancestor of Cultivated Common Buckwheat, and of Tatary Buckwheat. Econ. Bot. 52, 2, 123-133. https://doi.org/10.1007/BF02861199

Panche A. N., Diwan A. D., Chandra S. R. 2016. Flavonoids: an overview. J. Nutr. Sci. 5, e47. https://doi.org/10.1017/jns.2016.41

Pilon-Smits E. A. H., Quinn C. F., Tapken W., Malagoli M., Schiavon M. 2009. Physiological functions pf beneficial elements. Curr. Opin. Plant Biol. 12, 267-274. https://doi.org/10.1016/j.pbi.2009.04.009

Rady M. M., Belal H. E. E., Gadallah F. M., Semida W. M. 2020. Selenium application in two methods promotes drought tolerance in Solanum lycopersicum plant by inducing the antioxidant defense system. Sci. Hortic. 266, 109290. https://doi.org/10.1016/j.scienta.2020.109290

Roblek M., Germ M., Trošt Sedej T., Gaberščik A. 2008. Morphological and biochemical variations in St. John’s wort, Hypericum perforatum L., growing over altitudinal and UV-B radiation gradients. Period. Boil. 110, 3, 257-262. https://www.researchgate.net/publication/27216085

Rozema J., Staaij J. van de, Björn L. O., Caldwell M. 1997. UV-B as an environmental factor in plant life: stress and regulation. Trends Ecol. Evol. 12, 1, 22-28. https://doi.org/10.1016/S0169-5347(96)10062-8

Schreiber U., Bilger W., Hormann H., Neubauer C. 1998. Photosynthesis, a Comprehensive Treatise: Chlorophyll Fluorescence as a Diagnostic Tool: Basics and Some Aspects of Practical Relevance. Raghavendra A. S. (ur.). Cambridge: Cambridge University Press: 320-336 
Smolen S., Kowalska I., Sady W. 2014. Assessment of biofortification with iodine and selenium of lettuce cultivated in the NFT hydroponic system. Sci. Hortic. 166, 9-16. https://doi.org/10.1016/j.scienta.2013.11.011

Štroch M., Lenk S., Navrátil M., Špunda V., Buschmann C. 2008. Epidermal UV-shielding and photosystem II adjustment in wild type and chlorina f2 mutant of barley during exposure to increased PAR and UV-radiation. Environ. Exp. Bot. 64, 271-278. https://doi.org/10.1016/j.envexpbot.2008.05.007

Treml J., Šmejkal K. 2016. Flavonoids as Potent Scavengers of Hydroxyl Radicals. Compr. Rev. Food Sci. Food Saf. 15, 720-738. https://doi.org/10.1111/1541-4337.12204

Trippe III R. C., Pilon-Smits E. A. H. 2021. Selenium transport and metabolism in plants: Phytoremediation and biofortification implications. J. Hazard. Mater. 404, B. https://doi.org/10.1016/j.jhazmat.2020.124178

Van de Staaij J. W. M., Huijsmans R., Ernst W. H. O., Rozema J. 1995. The effect of elevated UV-B (280-320 nm) radiation levels on Silene vulgaris: A comparison between a highland and a lowland population. Environ. Pollut. 90, 3, 357-362. https://doi.org/10.1016/0269-7491(95)00015-J

Verdaguer D., Jansen M. A. K., Llorens L., Morales L. O., Neugart S. 2017. UV-A radiation effects on higher plants: Exploring the known unknown. Plant Sci. 255, 72-81. https://doi.org/10.1016/j.plantsci.2016.11.014

Zhang K., He M., Fan Y., Zhao H., Gao B., Yang K., Li F., Tang Y., Gao Q., Lin T., Quinet M., Janovská D., Meglič V., Kwiatkowski J., Romanova O., Chrungoo N., Suzuki T., Luthar Z., Germ M., Woo S.-H., Georgiev M. I., Zhou M. 2021. Resequencing of global Tartary buckwheat accessions reveals multiple domestication events and key loci associated with agronomic traits. Genome Biol. 22, 23. https://doi.org/10.1186/s13059-020-02217-7

\section{IZVLEČEK}

\section{Odgovor navadne in tatarske ajde na različnih nadmorskih višinah na dodatek selena}

Namen raziskave je bil preučiti odziv dveh vrst ajde na razmere, ki so na različnih nadmorskih višinah, ter morebiten vpliv foliarnega dodatka selena (Se) na njihove biokemijske, fiziološke in anatomske lastnosti. Navadno ajdo (Fagopyrum esculentum Moench) in tatarsko ajdo (Fagopyrum tataricum (L.) Gaertn.) smo posejali na prostem na treh lokacijah z različnimi nadmorskimi višinami $(300 \mathrm{~m}, 600 \mathrm{~m}$ in $1180 \mathrm{~m}$. n. m.) ter ju foliarno tretirali s kalijevim selenatom (10 mg Se L-1). Spremljali smo izbrane biokemijske, fiziološke in anatomske lastnosti ter primerjali rezultate med tretirano in kontrolno skupino ter med rastlinami, vzgojenimi na različnih nadmorskih višinah. Statistične analize smo izvedli znotraj posamezne vrste. Dodatek Se je povečal vsebnost UV absorbirajočih snovi pri obeh vrstah ajde, gojenih na najvišji nadmorski višini. Tretirana navadna ajda s te nadmorske višine ima najvišjo vsebnost UV absorbirajočih snovi. Se je zmanjšal število kristalov Ca-oksalata pri navadni ajdi, ki je uspevala na najvišji nadmorski višini. Dodatek Se ni vplival na vsebnost klorofila. Med rastlinami iste vrste in tretmaja so bile prisotne sledeče razlike v vsebnosti klorofilov: tretirane rastline navadne ajde iz Ljubljane (najnižja nadmorska višina) so vsebovale več klorofilov kot tiste iz Podbež, netretirane rastline iz Ljubljane pa več klorofilov kot tiste iz Javorja (najvišja nadmorska višina). Netretirane rastline tatarske ajde iz Javorja so vsebovale več klorofila kot rastline iz Podbež. Pri obeh vrstah ajde smo zabeležili nekaj razlik v številu kristalov Ca-oksalata med rastlinami iste obravnave na različnih nadmorskih višinah. Pri tretirani navadni ajdi je bilo njihovo število največje na najnižji nadmorski višini. Tam je bilo število kristalov Ca-oksalata tudi pri netretirani tatarski ajdi večje kot v Javorju. Pri tretirani tatarski ajdi je bilo število kristalov Ca-oksalata pri rastlinah iz Podbežah nižje kot pri rastlinah iz Ljubljane. Glede na rezultate meritev fotokemične učinkovitosti fotosistema II, ki so pokazale dobro fiziološko stanje rastlin obeh vrst iz tretirane in kontrolne skupine na vseh treh nadmorskih višinah, lahko zaključimo, da so poskusne rastline dobro prilagojene na razmere na različnih nadmorskih višinah in da dodatek Se za rastline ni predstavljal stresa. 